\title{
Os fundamentos históricos do protestantismo brasileiro - uma introdução
}

\author{
Wilson Santana ${ }^{1}$
}

\begin{abstract}
Resumo:
Este artigo apresenta uma introdução à história do protestantismo no Brasil, abordando as diversas fases da presença dessa vertente do cristianismo aqui desde o período colonial. O texto discute as ações protestantes franceses no século XVI no Rio de Janeiro, dos holandeses na região que hoje é o nordeste brasileiro, dos imigrantes de origem europeia durante o século XIX e, finalmente o chamado protestantismo de missões, instalado no país a partir da secunda metade do século XIX e que se consolidaria ao longo do século XX. Destaca, por meio da literatura produzida e ou distribuída por esses protestantes nos referidos contextos e, herdeira do movimento reformador do século XVI, tinha como ideal, devido às suas convicções religiosas, submissas ao ensino bíblico, a promoção das liberdade individual e da responsabilidade pelas implicações mais amplas da ética reformada para o desenvolvimento social, tendo a educação como um dos principais meios para que os seus objetivos fossem alcançados.
\end{abstract}

Palavras-Chave: História; Protestantismo Brasileiro; Liberdade; Educação

\section{The Historical Foundations of Brazilian Protestantism - An Introduction}

\begin{abstract}
:
This article presents an introduction to the history of Protestantism in Brazil, approaching the different phases of the presence of this strand of Christianity here since the colonial period. The text discusses the actions of French Protestants in the 16th century in Rio de Janeiro, of the Dutch in the region that is today the northeast of Brazil, of immigrants of European origin during the 19th century and, finally, the so-called Protestantism of missions, installed in the country from the second half of the nineteenth century and that would be consolidated throughout the twentieth century. It highlights, through the literature produced and or distributed by these Protestants in these contexts and, heir to the reform movement of the 16th century, had as an ideal, due to their religious convictions, submissive to biblical teaching, the promotion of individual freedom and responsibility for broader implications of Reformed ethics for social development, it has education as one of the main means of achieving its goals.
\end{abstract}

Keywords: History; Brazilian Protestantism; Freedom; Education

\footnotetext{
${ }^{1}$ Doutor em Ciências da Religião. Professor da Universidade Presbiteriana Mackenzie e do Seminário Teológico Presbiteriano Rev. José Manoel da Conceição. E-mail: wilson.santana@mackenzie.br. ORCID: https://orcid.org/0000-0001-8548-8321.
} 


\section{Los fundamentos históricos del protestantismo brasileño: una introducción}

\section{Resumen:}

Este artículo presenta una introducción a la historia del protestantismo en Brasil, abordando las diferentes fases de la presencia de esta vertiente del cristianismo aquí desde el período colonial. El texto analiza las acciones de los protestantes franceses en el siglo XVI en Río de Janeiro, de los holandeses en la región que hoy es el noreste de Brasil, de los inmigrantes de origen europeo durante el siglo XIX y, finalmente, el llamado protestantismo de misiones, instaladas en el país desde la segunda mitad del siglo XIX y que se consolidarían a lo largo del siglo XX. Se destaca, a través de la literatura producida y / o distribuida por estos protestantes en estos contextos y, heredera del movimiento reformista del siglo XVI, tuvo como ideal, por sus convicciones religiosas, sumisa a la enseñanza bíblica, la promoción de la libertad individual y responsabilidad de las implicaciones más amplias de la ética reformada para el desarrollo social, con la educación como uno de los principales medios para lograr sus objetivos.

Palabras clave: Historia; Protestantismo brasileño; Libertad; Educación

\section{INTRODUÇÃO}

O retorno ao Brasil quinhentista, inevitavelmente, projeta o leitor a rica experiência do conhecimento, de fatores que levaram certo número de franceses a uma tentativa de se implantar no Atlântico Sul, uma França Antártica.

O período em destaque, atraiu e tem atraído muitos pesquisadores, tanto franceses quanto brasileiros. A historiografia religiosa e a histórica têm despertado o interesse de estudantes e intelectuais de diversas áreas do conhecimento. Muito mais que simples disputas religiosas, a França Antártica tem ao longo dos anos oferecido boa variedade de temas, como: protestantismo, huguenotes, catolicismo, políticas internacionais, conflitos religiosos, etnografias, antropologia histórica, entre outros. Longe de esgotar o assunto, o artigo propõe uma breve introdução do conteúdo, facilmente a disposição dos leitores.

O mesmo ocorre na apresentação do Brasil Holandês. Procurou-se, aqui, resumidamente, demonstrar a participação eloquente e competente, do Conde Mauricio de Nassau. Neste subtópico o leitor terá a oportunidade de vislumbrar uma enorme tentativa de se trazer modernidades e desenvolvimentos para as regiões ocupadas pelos calvinistas.

O período seguinte, caracterizou-se pela ausência de tentativas para se ocupar um território brasileiro por nações protestantes. É convicção do autor deste trabalho, que a 
presença do Marquês de Pombal e suas reformas na sociedade portuguesa, muito contribuiu para profundas mudanças na mentalidade luso-brasileira.

A presença da monarquia portuguesa no Brasil, desde 1808, favoreceu significativamente a obtenção, por parte de protestantes anglicanos, à desejada tolerância religiosa. Os tratados com a Inglaterra, 1810, e a carta constitucional de 1824, garantiram aos protestantes e outros cultos, a liberdade religiosa.

Na década de 30, já é possível perceber a atuação de missionários americanos, espalhando-se pelo território nacional, distribuindo bíblias, panfletos e outras literaturas impressas.

Finalmente, os fundamentos do protestantismo começaram a ganhar forma para receber sobre si um complexo edifício. O artigo não ultrapassa o final do século XIX, porém, ressalta que foi na segunda metade do citado século que: Congregacionais, Presbiterianos, Metodistas e os Batistas se organizaram. O corte temporal até o século XIX, parece ser o suficiente, tratando-se de uma introdução, para se verificar o movimento de homens e instituições, ainda que estrangeiros, foram protegidos pelas leis da segunda monarquia.

\section{A FRANÇA ANTÁRTICA - BRASIL SÉC XVI}

O evento da "França Antártica", ocorrido na segunda metade do século XVI, constitui-se um vasto campo de conhecimento e pesquisa, capaz de lançar luz sobre questões relevantes envolvendo homens, políticas e nações.

A França ressentiu-se quando o tratado de Tordesilhas (1494), entre Portugal e Espanha com o consentimento papal, destinou as novas terras a serem descobertas às nações Ibéricas, deixando-a excluída e sem possibilidade de recursos.

Para os franceses não havia justificativas que "as novas terras", com dimensões incalculáveis, tornassem propriedades exclusivas de Portugal. Tanto D. Manoel quanto os seus sucessores estariam dispostos a declarar guerras contra Francisco I, Carlos V ou a qualquer outro soberano que ousasse questionar ou invadir suas novas possessões.

Pouca importância, nobres, marinheiros, normandos e bretões, aliados aos franceses, deram as proibições de Portugal quanto ao Novo Mundo. É fato que inúmeros navios com suas cartas de corso frequentavam insistentemente as costas do Brasil, extraindo destes produtos e madeiras, consumidos e distribuídos nos portos franceses. 
Em 1555, governava o Brasil D. Duarte da Costa, que concentrava as suas atenções as regiões ao norte da colônia. Muito provavelmente, conhecendo o comportamento dos governantes coloniais que deixavam totalmente descoberta a região sul, aproveitaram os franceses a oportunidade e se instalaram com propósito colonial na região da Baia de Guanabara.

A descrição acima faz-se necessária para o entendimento do estabelecimento do projeto de Nicolau Durand de Villegagnon para a implantação da sua França Antártica. Já estabelecido na pequena ilha de Serigipe, concentrava-se integralmente e dedicava-se a construção de um forte, casas para os colonos e proteção contra os prováveis invasores.

O Vice-Almirante possuía prestigiosa formação cultural e acadêmica. O Cavalheiro de Malta possuía formação teológica até o grau de doutorado.

O historiador Philippe Bonnichon, oferece preciosos dados biográficos e descreve Villegagnon como "condiscípulo de Calvino" (BONNICHON, 1975, p.428). Tanto Calvino como Villegagnon eram franceses. Calvino nasceu no ano de 1509 e Villegagnon em 1510. Os dois fizeram estudos teológicos na mesma época em Paris.

A França, em Villegagnon, tem um aventureiro, um militar navegante e um intelectual com formação teológica. O novo ambiente, cria em Villegagnon uma mentalidade obsidional, termo utilizado por Bonnichon. (BONNICHON, 1975)

À medida que o tempo fluía, ficava cada vez mais claro a intranquilidade e a insuportabilidade dos colonizadores que em tudo projetavam dificuldades. $\mathrm{O}$ comportamento moral de cada um deles era vigiado com rigor e em situações extremas, caso não aceitassem os corretivos, usava-se inclusive a força de guardas. Também ficou evidente que sem a associação e a cooperação dos indígenas, o abastecimento alimentar da colônia ficaria impossível. Além disso, percebia-se que o auxílio, os provimentos e a munições vindos da França eram necessários e sem eles seria impossível a manutenção do novo empreendimento.

Finalmente em 7 de março de 1557, vislumbrou-se na linha do horizonte, daquela baia, o auxílio tão desejado e esperado. Grande foi a euforia e manifestações de contentamento. Tiros de canhões foram trocados para recepcionar aqueles que para Villegagnon eram os portadores de uma nova esperança e iniciadores de uma Igreja Reformada, no Novo Mundo. 
Aqueles navios e seus marinheiros que acabavam de chegar, fizeram uma difícil travessia pelo Atlântico. Bois-le-Comte, impetuoso sobrinho de Villegagnon tomava decisões precipitadas e arriscadas. Atirando e saqueando navios mais frágeis e já cansados de longas viagens. Entre a tripulação estavam catorze huguenotes. Estes, com uma compreensão de mundo adquirida através dos sermões e aulas de Calvino e seus pastores auxiliares, atiraram-se, sob a proteção de Deus a uma geografia e um mundo totalmente desconhecido e novo. Dentre eles, Jean de Léry, um jovem talentoso, estudante de teologia, por ofício era sapateiro, dotado da arte de educar, narrar e historiar.

Jean de Léry em sua obra "Viagem a Terra do Brasil", registra que a recepção aos novos colonos foi muito calorosa e que de imediato a 10 de março de 1557, data em que os navios atracaram com segurança e quando a tripulação desembarcou, o Vice-Almirante convocou todos os colonos e após palavras de ordem fez com que os ministros protestantes, recém-chegados, realizassem culto de gratidão ao Soberano Deus, conforme a liturgia da Igreja Reformada de Genebra.

Esta celebração, conduzida pelo reverendo Richier, o primeiro culto protestante em solo americano, constou de sermão baseado no salmo 27 versículos 4: "Uma coisa peço ao Senhor, e a buscarei: que eu possa morar na Casa do Senhor todos os dias da minha vida, para contemplar a beleza do Senhor e meditar no seu templo”. Cantaram pela primeira vez, com métrica e melodia do saltério de Genebra, o Salmo número 5. Após a cerimônia, comenta Léry que ordens foram dadas para que todos empenhassem-se nos reparos e nas construções que ali se desenvolviam.

Em 21 de março, onze dias após o primeiro culto, celebrou-se pela primeira vez a eucaristia. Curiosamente, e com alguma surpresa para Léry, que também presenciou e registrou, uma oração pública foi feita pelo Vice-Almirante Villegagnon, através desta oração verifica-se a capacidade com que o orador tratava questões teológicas.

Ao terminar o sermão, Villegagnon, apresentando zelo, levantou-se e alegou que os capitães, mestres, marujos e algumas pessoas presentes ainda não professaram a religião reformada; deviam, portanto, sair porque não estavam aptas para assistir ao ministério da administração do pão e do vinho. E ele próprio a fim de dedicar o seu fortim a Deus e fazer confissão de sua fé em face da igreja, ajoelhou-se num coxim de veludo, que um pajem trazia geralmente consigo, e pronunciou em voz alta duas orações. (LÉRY, 2007, p.91)

Rendo-te graças, meu Deus, de todo o coração, por te haveres dignado tirar-me do mundo em que vivia, por ambição, para colocar-me no lugar onde com toda a liberdade e todas as minhas forças eu possa contribuir 
para o aumento de teu santo Reino [...] E ainda te aprouve não só permitir que lançassem raízes neste lugar aqueles que para aqui trouxeste sãos e salvos, como também estabeleceste o regime de uma igreja para manter-nos unidos e no temor de teu santo nome a fim de ganharmos a vida eterna. [...] Peço-te também, senhor e pai nosso, que estendas a tua benção sobre este forte de Coligny e essa região da França Antártica, para que se torne inexpugnável o refúgio daqueles que em boa consciência e sem hipocrisia aqui se abrigarem a fim de dedicar-se conosco à exaltação da tua glória, e para que possamos invocar-te no seio da verdade sem sermos perturbados pelos hereges. [...] Praza a ti também, ó Deus de bondade, proteger o Rei, nosso Soberano e Senhor, bem como sua mulher, sua progênie e seu conselho, e ainda o senhor Gaspar de Coligny, sua mulher e sua descendência, conservando-os todos na vontade de manter e defender esta tua igreja; e condescende em dar a este teu humilde escravo a prudência necessária para dirigir-se, de maneira a não se desviar do verdadeiro caminho e a resistir a todos os obstáculos que Satã.[...] a fim de que possam reconhecer-nos como teus filhos; e se te ofendermos permite, senhor de misericórdia, lavarmos os nossos pecados no sangue de teu filho, lembrando-te de que fomos concebidos na iniquidade e de que, pela desobediência de Adão, em nós reside o pecado. (LERY, 2017, p. 91 93)

Em tudo, comportamentos, ações, projetos e relações interpessoais, Villegagnon demonstrava inteira satisfação com a presença e as ideias do grupo enviado por Coligny e Calvino.

Após demonstrar gratidão a Calvino por carta e aos irmãos enviados, declara estar menos ansioso por contar com aqueles irmãos para arrefecer o ímpeto e a frouxidão de comportamentos existentes nos colonos.

Em curiosa carta que Villegagnon enviou a Calvino em 31 de março de 1557, apenas 10 dias após a primeira ministração da Santa Ceia, encontram-se registros que revelavam as inquietações e o pensamento interiorizado deste comandante. Também oferece a Calvino uma visão do Brasil e de seus habitantes.

Segundo ele:

O país era completamente selvagem, afastados de toda cultura e humanidade; diferenciados de nós pelos costumes e regras de vida, sem religião, sem conhecimento nenhum do que seja a honra, a virtude, incapazes de distinguir o justo do injusto, tanto que me veio a dúvida se tínhamos encontrado feras revestidas de aparência humana. (SALVADOR, 2001, p.174) 
Informa através da carta a Calvino que sua vida tem sido muito agitada em função das exigências de seu cargo como administrador. Comenta dissabores externos praticados pelos portugueses, que os não perdoavam pelo domínio da região. Questões internas envolvendo imoralidades, revoltas, traições, falta de víveres, ocupavam a sua mente e exigiam mão de ferro na condução do complexo povoamento. Com certo pesar narra que sua vida esteve por um fio diante de vinte e seis sediciosos. Os dias eram intranquilos. Também comenta que com a chegada da segunda expedição e a presença dos huguenotes, suas forças foram renovadas, podendo inclusive constituir um conselho com doze membros, cuja prerrogativa era tratar das questões envolvendo os colonos e os seus projetos.

Surpreendentemente Villegagnon encerra a missiva declarando que os conselhos de Calvino serão por todos atendidos, pois não existe homem mais santo, nem mais reto, nem mais sadio que o reformador genebrino:

\begin{abstract}
Acrescentarei o conselho que colocaste em tua carta: é preciso entregarse à obra com toda a absorção da alma, a fim de não nos permitirmos qualquer desvio por pequeno que seja. Estou certo de que não existe luminar mais santo, nem mais reto, nem mais sadio. Por isso tivemos o cuidado de ler a tua carta em o nosso senado e transcrevê-la, nas atas, a fim de que se acontecer de nos afastarmos de nossa linha, a leitura desta nos reconduza do erro. (SALVADOR, 2001, p.177).
\end{abstract}

A forma educada e respeitosa com que se refere a Calvino, demonstra algum conhecimento anterior e relacionamentos mais próximos com o líder da reforma em Genebra. No entanto este quadro iria sofrer profunda alteração em período inacreditavelmente curto. Assim como, diante de sol claro, avizinha-se nuvens espessas e escuras, e o bom tempo transforma-se em violentas tempestades.

Inesperada e inexplicavelmente o caos se instaura no relacionamento entre o ViceAlmirante e o grupo dos huguenotes. Questões variadas e de pouca importância, ampliaram-se no campo das discussões intermináveis e sem concordância, rasgavam o bom relacionamento entre o anfitrião e seus convidados.

No passar dos dias, nada se resolvia, pelo contrário, ânimos exaltados apontavam para um desfecho nada animador.

Diante de tal quadro, Jean de Léry, impelido pelos maus tratos recebidos em muitas oportunidades, se deslocava para junto dos Tupinambás e com os quais inicia, uma interessante amizade. É o próprio Léry que narra em sua "Viagem a Terra do Brasil", 
como viveu e aprendeu significativos detalhes do costume e da cultura daqueles selvagens.

A experiencia de Léry é muito parecida com a vivida pelo alemão Hans Staden. No entanto o refinamento intelectual do francês lança luzes ainda mais claras sobre a vida dos Tupinambás, superando as valiosas observações feitas pelo náufrago alemão. A convivência com os Tupinambás não durou mais que um ano, tempo suficiente para uma imersão completa na cultura dos seus novos anfitriões.

As guerras religiosas na França o deslocaram para Genebra. E agora no Brasil, novamente, Léry se depara com as velhas questões de intolerância que o faz migrar do forte Coligny para as margens habitadas pelos naturais da terra. Os Tupinambás o recepcionam sem preconceitos e dispostos a compartilhar tudo o que fosse necessário para a sobrevivência, segundo eles do diferente francês. Léry aprende a fauna, a flora, guerras, comportamentos, hábitos alimentares, caça, pesca, núcleos familiares e até mesmo mitos e lendas enraizados no coletivo e no individual daquela etnia.

Entre muitas cerimonias que aquele povo praticava, Léry destaca uma em específico. Aconselhado a não participar, antes ficando com a mulheres. Não se controlando, abrindo caminho entre a palha. Em secreto ficou extasiado com os sons e cantos que o grande agrupamento de homens produzia.

Em algum momento a tradição ocidental do calvinista implorava para que movimentos objetivos fossem dados na direção de uma sistematização e racionalidade no trato da língua e história daqueles homens. Ainda que o trabalho individual desenvolvido por ele fosse penoso e árduo, não baixou sua guarda, pelo contrário, iniciou o processo em que as palavras seriam representadas por símbolos.

Para os ameríndios, o uso de cartas pelos invasores era muito estranho e inexplicável a maneira como se comunicavam através delas. Acreditavam, tratar-se de feitiçaria. Não entendiam como uma folha de papel atravessando oceanos, era capaz de levar notícias e trazê-las. Todo este mistério foi desvendado por Léry, quando iniciou e terminou um dicionário Tupinambá.

Em sua obra clássica, "A Escrita da História”, Michel de Certeau desenvolve um dos mais belos e profundos capítulos sobre Jean de Léry: ETNO-GRAFIA - A oralidade ou o espaço do outro. Temas como: a oralidade, a espacialidade, a alteridade e a 
inconsciência, são analisados. Este capítulo é indispensável para qualquer estudante interessado em desvendar as primeiras discursões sobre antropologia. (CERTEAU, 1982)

O escritor Lima Barreto, em sua obra "O Triste fim de Policarpo Quaresma", nas sessões iniciais, coloca Jean de Léry entre os autores prediletos de seu personagem e instiga os leitores a investigarem a etnografia e a antropologia. O que mais pesa no evento "França Antártica" foi o cruel assassinato de três calvinistas que presos dentro de uma choupana, escreveram sob a mão de ferro de Villegagnon, um belíssimo documento, que passou para a história como "A Confissão de Fé Fluminense", em que eles escreveram e defenderam com "tinta do pau brasil", as verdades evangélicas em que criam.

Fica evidente que há muito para escrever sobre tal tema, no entanto falta aqui espaço para maior aprofundamento. Em Léry fica evidente a sua intencionalidade em transformar a totalidade daquele mundo oral em fragmentos de signos, símbolos e sons que representavam palavras.

As convicções de fé reformada pulsavam freneticamente naquele jovem sapateiro. A transmissão das convicções evangélicas aos Tupinambás foi inevitável. Desta maneira Léry agia e se comportava como pastor de almas e ao mesmo tempo exímio pedagogo em questões naturais e intelectuais.

\section{O BRASIL HOLANDES - SEC. XVII}

A letra do hino nacional da Holanda, destaca uma menção ao soberano da Espanha: "O rei da Espanha eu sempre honrei”.

As relações entre Espanha e os Países Baixos nem sempre foram amistosas como aparece acima. Pelo contrário em momentos históricos, envolvendo os dois povos ocorreram profundas desavenças, fraturas, ódio e tensão. A Espanha por muitas décadas manteve domínio sobre aquela região. Diversas foram as tentativas dos Países Baixos por sua independência. Consequentemente, as reações dos soberanos espanhóis e aliados geravam violentas e sangrentas batalhas. Evidente que a soberania espanhola era imposta através das mãos de ferro e das armas dos seus comandantes.

O monolítico domínio Espanhol sobre aqueles povos começou a colapsar quando, no ano de 1588, a rainha Elizabeth I da Inglaterra impôs, através da sua marinha, uma humilhante derrota sobre a "invencível armada espanhola" do rei Felipe II. 
Dez anos antes dos desastrosos resultados do canal da mancha, a Espanha tornarase a mais poderosa nação europeia e provavelmente do globo. Isso se deu quando a nação portuguesa e todas as suas colônias passaram a pertencer a já poderosa Espanha.

Com a morte do rei D. Sebastião no ano de 1578, na batalha de Alcácer-Quibir, o trono português ficou sem sucessor. Felipe II, cuja mãe pertencia a nobreza portuguesa, tinha direito ao trono. No ano de 1580, após muitos tratados específicos quanto ao modo da nova dinastia dirigir Portugal, celebrou-se a histórica União Ibérica.

Em processo dinâmico e aproveitando-se da fragorosa derrota espanhola, a Holanda se ergue a sombra da sua vizinha Inglaterra e sistematicamente vai vencendo os seus opressores em todos os flancos. A Espanha imobilizada e com imensas dívidas de guerra, não tinha o que fazer. Comenta Lessa (1937, p.35): “A fatal expedição à Inglaterra marcou o início da decadência da Espanha. Debilitado ficou o poder militar e recursos imensos foram consumidos nos planos de Philippe II, quando antevia a monarquia universal”. A hegemonia dos mares por tantos séculos em suas mãos, agora escapa para as mãos Inglesas e holandesas.

Do ponto de vista territorial, sua localização e os profundos desafios físicos do seu restrito espaço continental, sua geopolítica deveriam catapultá-la cada vez mais para o abismo, porém o efeito foi o contrário. As províncias que formavam o pequeno país fortaleceram-se acolhendo refugiados por perseguições religiosas, judeus em abundância e qualquer indivíduo ou grupo que fossem feridos quanto a suas convicções de liberdade, fundamentalmente a religiosa. Dados históricos comprovam que tal foi a violência e perseguições dos espanhóis que cerca de cem mil famílias protestantes, a verdadeira flor da nação, emigrassem dos Países Baixos do Sul (Bélgica) para as bandas do norte, Holanda e Zelândia sobretudo, trazendo assim o seu contingente para a prosperidade da região do norte. (LESSA, 1937)

Em um futuro próximo, outros seguiriam o mesmo caminho: luteranos, reformados, huguenotes, puritanos, anabatistas, judeus, filósofos, comerciantes, artesãos liberais, foram todos abraçados e despertados a começar uma nova vida dentro das fronteiras daquele país em que as liberdades imperavam.

No começo do século XVII esta Holanda organizada, cria mecanismos de produção industrial e intensifica seu já vantajoso comercio, especializando-se na construção de estaleiros e grandes navios mercantes e de armas. Esses navios foram 
frequentemente negociados com várias nações. Grandes empresas como a Companhia das Índias Orientais (1602) e a Companhia da Índias Ocidentais (1621), abriram os oceanos e o comércio com o extremo Asiático, África e as Américas, abasteciam os portos holandeses e proporcionavam rendas a todos os seus investidores.

Destaca-se que entre 1618-1619, travaram-se grandes debates no Sínodo de Dorth. O calvinismo prevaleceu e a igreja reformada firmou ali sua hegemonia.

A criação da Companhia das Índias Ocidentais era uma forte evidência que, antigas dívidas com a Espanha, seriam cobradas.

O plano de Usselinex e de seus confrades, mercadores da Flandres e do Brabante, consistia na organização de uma empresa particular de grandes recursos para ir ao encalço das colônias espanholas, conquistando-as e apresando-lhes as riquezas transportadas". (LESSA, 1937, p. 40)

Em 1624, chegou à Bahia, Capital do Brasil, uma esquadra holandesa comandada pelo Almirante Jacob Willekens e Piet Heyn o vice-almirante. Eram vinte três navios e três iates, guarnecidos com quinhentas peças de artilharia, mil e seiscentos marinheiros e mil e setecentos homens de desembarque, ao comando do coronel Van Dorth, que seria o governador das terras conquistadas. (LESSA, 1937)

A cidade foi atacada de madrugada. O governador, que reagira foi capturado e deportado para a Holanda. Após um ano dominando os soteropolitanos, os holandeses não resistiram ao ataque bem planejado de uma forte esquadra, comandada pelo almirante D. Fradique de Toledo Osorio, com cinquenta e dois navios e doze mil homens de guerra, marinheiros e soldados, que surgiram na cidade do Salvador aos 29 de março de 1625. Foi um cerco eficaz e o fim do domínio holandês naquele ano em terras baianas. (LESSA, 1937)

Entre 1630 e 1636, os holandeses, já estabelecidos no Brasil, dominavam o litoral desde o Maranhão até a foz do rio S. Francisco. Para tomar posse dessas terras, organizar a conquista e prosseguir no plano de desenvolvimento, a Holanda escolheu um governador inteligente, culto e nobre, o jovem Conde João Mauricio de Nassau, natural de Siegen, que chegou ao Brasil em 23 de janeiro de 1637. "sendo recebido solenemente por todas as autoridades civis e militares, entre as aclamações dos habitantes". (SOUTO MAIOR, 1991, p.32) 
Em interessante crônica sobre Mauricio de Nassau, Gilberto Freire, no vigor dos seus 27 anos e com certa liberdade literária, tratou Nassau como o príncipe encantado com seus cachos dourados de contos da carochinha. Ao contrário de outros autores, Gilberto em sua honestidade histórica, trata o personagem com simpatia dosada, fugindo dos arroubos de uma retórica improdutiva. (FREIRE, 1979).

O Conde Mauricio via o Brasil como um dos mais belos países do Novo Mundo, possuidor de paisagens e orla marítima incomparáveis. (SOUTO MAIOR, 1991)

Gilberto Freire, afirma que o Recife encontrado por Nassau, não passava de um charco, abandonado, desprovido de tudo. Destaca também que o comandante holandês em curto período mudaria significativamente o futuro e a paisagem de toda aquela região. Trata-se de alguém, cuja missão no nordeste brasileiro seria a de implantar uma civilização. Possuía Nassau o inquietante germe de modernidade. Recife se tornaria uma capsula de novidades.

O domínio espanhol sob a Holanda era matéria fresca e impregnada de eventos catastróficos que sempre avizinhava os pensamentos do Conde. Em lógica simples e a partir de observações empíricas, Nassau percebeu que os primeiros oitenta anos de colonização portuguesa somados a sessenta sob o domínio espanhol, pouquíssimos resultados haviam trazidos ao Brasil. Conhecia bem a administração e a política dos Habsburgos. Para os reis católicos espanhóis, tanto Portugal como o Brasil constituíamse em matéria de somenos importância. Explorava-se ao máximo e quase nada era oferecido.

Mauricio, protestante convicto, compreendia bem a Cosmovisão Reformada, baseada em antigas convicções e símbolos calvinistas. Ele era observador e agente, de um mundo, extraordinário teatro, em que dia após dia ocorrem manifestações de um Deus que é Soberano.

Para o Conde, a sua permanência no Brasil deveria proporcionar, não só a excelência administrativa e os lucros exigidos por seus senhores, mas também provocar melhorias e tornar-se agente de profundas mudanças do status quo da sofrida gente pernambucana.

A convite de Nassau, para implementar os seus auspiciosos projetos, desembarcariam no Brasil excelentes quadros de inteligências humanas. Lessa (1937, p.171) escreve: "Uma das provas do bom gosto e das altas qualidades administrativas de 
Nassau decorre da comitiva de sábios e artistas que o acompanharam na sua vinda a Pernambuco, acrescida de outros que passaram depois ao Brasil a seu convite".

Entre aqueles de maior confiança para Nassau estava seu capelão, ministro evangélico Francisco Plante. Muito versado em latim, poeta. Sua fama, muito se deu, pelas ações conciliatórias entre os expoentes do culto calvinista e do católico. Velando sempre pela tolerância e pela harmonia. Retornando para a Holanda tornou-se professor de teologia em Breda. Propagou os feitos do conde Mauricio, inclusive compôs um poema em sua honra. Era uma epopeia biográfica em doze cantos, impressa em 1647, com quatro mapas do Brasil e vinte e duas gravuras copiadas de Barlaeus, e um precioso retrato do Conde, traçado pelo artista T. Matham. (LESSA, 1937)

Ser agente e expectador deste mundo, teatro de Deus ${ }^{2}$, implicava em tomadas de decisões e ações que deveriam beneficiar o ser humano independentemente de sua raça, credo, condições sociais e educacionais. Muito contribuiu para a sociedade brasileira, como para aquele acúmulo de povos existentes na costa brasileira, a vinda de Guilherme Piso, ilustre conselheiro e médico de Nassau. Possuía grande fama em Leyde e Amsterdam, no exercício da medicina, escritor e naturalista. (LESSA, 1937)

Outro, ilustre membro da seleta comitiva de Nassau foi Jorge Markgraf. Ele era alemão, natural de Liebstadt, na Saxônia. Tinha formação erudita em diversas áreas do conhecimento, como: geografo, botânico, zoólogo e cartografo. Porém seus conhecimentos na física e astronomia era de profundo cientificismo. Tendo Galileu Galilei em 1609 aproximadamente desenvolvido a luneta, ele, Markgraf, nos dias de Nassau, transportava da Holanda para o Brasil, dentro de porões de grandes naus, um completo e complexo laboratório astronômico, que a seu tempo foi montado e colocado em funcionamento, com o objetivo de desvendar e observar os movimentos dos astros no céu brasileiro. Teve também a oportunidade de examinar as constelações até então desconhecidas no mundo científico. (LESSA, 1937)

Destaca-se o refinamento estético e urbanístico de Nassau. A topografia recifense era de difícil domínio, pois o oceano, o rio Capibaribe e o continente se encontram. Apresentando certa semelhança com as agressivas terras holandesas.

Gilberto Freire (1979, p. 382) escreve: "Nassau encontrou um Recife menos que burgo podre. Miserável burgo de marítimos". Pelo que tudo indica o local, não oferecia

\footnotetext{
${ }^{2}$ João Calvino, instituição da religião cristã, livro 1, sessão 8.
} 
condições mínimas de moradia. Despertou-se o gênio da imaginação de Nassau quando, contrariando ordens superiores, e por iniciativa e recursos próprios, adquiriu a considerada inabitável ilha de Antônio Vaz.

Com certo humor o quadro criado por Freire, quanto a compra da dita ilha é revelador. A pequena vila exprimida precisava urgentemente expandir-se, mal se observava a superfície de uma ilha, quase submersa que se destinava mais a rãs do que a homens. A total desaprovação dos caixeiros holandeses, quanto a compra da ilha, em nada alterou os ambiciosos projetos do Conde. (FREIRE, 1979)

Drenou os pântanos e mangues, aterrou regiões baixas. Construiu pontes, canais e edificou uma cidade com dois belos palácios que serviriam para sede do governo e para sua moradia.

Relatórios encaminhados as autoridades da Holanda descrevem os benefícios feitos ao Recife por Nassau, dentre eles: um manuseio e plantio de milhares de árvores nativas e das costas africanas. Tal exuberância que mais ao norte um jardim parque surgiu com tamanha eficácia e beleza. Por compreender Mauricio que era preciso dar pulmões a nova cidade. (FREIRE, 1979)

Nassau foi incentivador e mecenas de pintores como Frans Post e Albert Eckhout, suas pinturas retratam com muita beleza e precisão o cenário pernambucano, praticamente, em nossos dias extintos.

Recuperou velhos engenhos açucareiros e outros danificados pela fúria das intermitentes guerrilhas. Amparou lavradores, estimulou a cultura da cana de açúcar, fez empréstimos com recursos da companhia para senhores de engenho, luso-brasileiros e holandeses.

O segredo para se desvendar o cuidado e respeito administrativo, o zelo na ação pastoral e desprendimento missionário por parte das autoridades holandesas, está na compreensão do conceito calvinista de "teocracia". Segundo Grijp: "isso é, o desejo de subordinar todos os aspectos da vida, tanto particular como pública, aos mandamentos de Deus expressado na Sagrada Escritura”. (GRIJP, s/d, p.3)

Quanto ao estabelecimento da Igreja Reformada, Nassau contribuiu e deu continuidade para que se firmasse, com muito zelo, antigos projetos da companhia. Escreve Grijp (s/d, p.3): “A formação de paróquias reformadas seguiu de perto as conquistas territoriais, sendo que a maior e mais prestigiosa dessas paróquias, a do Recife, 
tomou em 1636 a iniciativa para uma organização regional, a classe, que formalmente dependia dos sínodos provinciais nos Países Baixos”.

Desta maneira, conforme assinalado acima, surgiu, com iniciativa da Igreja de Recife, o Sínodo Reformado, organismo eclesiástico administrativo que sob sua jurisdição mantinha dois Presbitérios com aproximadamente vinte igrejas e dezenas de congregações. Deu liberdade aos católicos e judeus para seguirem sua religião. Comenta Grijp (s/d, p.3): "Os católicos gozavam de liberdade para exercerem seu culto e manterem relações oficiais com a sede episcopal da Bahia. As sinagogas e escolas talmúdicas do Recife eram as primeiras que apareceram no Novo Mundo".

Em hipótese alguma foi pequeno o esforço dos líderes reformados em promover a evangelização ao maior número possível dos indígenas e da população em seu todo. Em 1638, David Doorenslaer, pastor predicante, atuava em aldeias constituídas na Paraíba, tendo a satisfação de, após dois anos de trabalho, entregar a ceia do Senhor aos primeiros convertidos. Também ficou acertado na organização sinodal a criação de um breve catecismo trilíngue: em tupi, holandês e português. Tal documento, provavelmente foi encaminhado para a impressão nos Países Baixo. (GRIJP, s/d)

Outra importante contribuição da estrutura holandesa para consolidação do evangelho no Brasil e em outras colônias de fala portuguesa foi o excepcional trabalho desenvolvido por João Ferreira de Almeida, servindo a Holanda como pastor predicante e tradutor. Ele era português, conheceu o protestantismo muito jovem e foi convidado a trabalhos missionários e de tradução no extremo asiático. A versão da bíblia conhecida como a de João Ferreira de Almeida é por excelência a mais usada por protestantes no Brasil. Participou da criação de casas de caridades, escolas, hospital, asilo para órfãos, onde também eram instruídos. Instalou biblioteca e museu; engrandeceu as letras, ciências e artes trazendo intelectuais e artistas de vários países europeus. (SOUTO MAIOR, 1991)

Embora considerado estrangeiro, foi ele o remodelador do Nordeste. A folha de serviços que o conde Mauricio construíra ao longo dos anos, obrigatoriamente levaria, no futuro, até mesmo, seus críticos, em páginas intermináveis tecerem os mais sinceros e ricos elogios a sua personalidade e aos seus feitos. 


\section{MARQUES DE POMBAL E SUAS REFORMAS - SEC. XVIII}

$\mathrm{Na}$ segunda metade do século XVIII, as relações entre Brasil e Portugal, mantinham-se dentro das condições de séculos anteriores. O Brasil com suas imensas dimensões e potenciais serviçalmente, cumpria como colônia obrigações impostas por Portugal, Metrópole europeia.

Metaforicamente, o Brasil era um desproporcional "apêndice" ligado e irrigado por todo tipo de fluxos que iam e vinham "de um frágil corpo" luso, que se demorava para convalescer-se e firmar.

O reinado de D. José I (1750-1777), ficou marcado por uma série de acontecimentos que alterariam significativamente estruturas portuguesas e de suas colônias. É provável que a presença de Sebastião José de Carvalho e Melo, o Marquês de Pombal, tenha em muito contribuído para tais mudanças. Diante e após o violento terremoto que abalou Lisboa, no primeiro dia de novembro de 1755, o Marquês cresceu exponencialmente diante da "Corte" e da sofrida população. Sua administração muito eficaz na reconstrução e reorganização da cidade arruinada, fez com que o seu nome, no futuro, aparecesse nas crônicas e história de Portugal.

Provocou alterações nas relações administrativas e comércio entre a metrópole e as colônias. Suspendeu as perseguições aos Judeus. Anulou a inquisição. Implantou indústrias de produtos básicos para abastecer a nação portuguesa.

O seu Regalismo consentido por D. José I foi ao extremo, ao expulsar os jesuítas de terras portuguesa em 1759 e do Brasil em 1760. A ordem Inaciana sofreu seu maior revés em 1773, ano em que foi extinta pelo papa Clemente XIV.

Pombal, cercou-se de muitos sábios e conselheiros que o influenciou quanto as profundas reformas implantadas na Universidade de Coimbra. Jansenista como Padre Antônio Pereira de Figueiredo e as ideias de Antônio Verney, com seu Verdadeiro método de estudar, foram fundamentais e colaboraram para as novas mudanças propostas. Sistematicamente professores da ordem dos oratorianos, organizada por Felipe de Nery foram assumindo paulatinamente as cadeiras deixadas pelos antigos Mestres Jesuítas.

Historiadores e críticos ressaltam que esta Reforma Educacional em Coimbra, iniciada por Pombal, com a participação direta dos professores oratorianos foi essencialmente culta e prática. Jamais vista naquela Universidade. 
O fim do século XVIII presenciou grandes revoluções: a Revolução Industrial na Inglaterra, a Revolução Americana em 1776 e a Revolução Francesa em 1789, e esta, provocando alguma inquietação na Europa. Com a morte de D. José I em 1777, foi grande a ruína do prestígio do Marquês de Pombal. D. Maria I, assumia no lugar de seu pai o trono português e imediatamente canalizou toda a sua indignação contra o primeiroministro.

Com o século XIX ainda nos primeiros anos, Portugal teve que enfrentar grandes agitações provocadas pela ascensão da França sob comando de Napoleão Bonaparte. A França, naqueles dias tornou-se muito forte e gestava um mirabolante plano de tornar-se senhora absoluta da Europa, incluindo as Ilhas Britânicas.

Napoleão exigiu que as relações entre Portugal e Inglaterra fossem rompidas e que todo o cidadão inglês vivendo em Portugal deveria ser expulso. Ordem que nunca foi acatada pelos portugueses.

O general Junot, com suas tropas atravessou o território espanhol, invadindo Portugal por terra, consta-se que o referido militar, já em território português não teve tempo suficiente para impedir a fuga da família real e da corte portuguesa, que em vários navios e escoltados pela marinha inglesa fugiram para a colônia brasileira. Comenta Rodrigues: "Vendo o seu Reino invadido por Junot e defendido por Ingleses, que auxiliavam os Portugueses, vendo de fato tudo perdido na Europa, a família real transmigrou para o Brasil”. (RODRIGUES, 1904, p. 95)

\section{REINO, INDEPENDÊNCIA E MONARQUIA - BRASIL SÉC. XIX}

Em terras brasileiras desde 1808, a rainha D. Maria I, seu filho príncipe regente e toda a estrutura e burocracia, política e econômica de Portugal, rapidamente esboçam um diagnóstico das condições da nova sede do reino.

Há seu tempo os importantes temas foram debatidos e aos poucos as mínimas condições burocráticas foram se estabelecendo e firmando-se no Rio de Janeiro. A antiga capital da colônia, desde 1763 , da noite para o dia transforma-se na capital do reino português.

Ressalta-se que os quadros de inteligências portuguesas, agora estabelecidos no Brasil, são na sua maioria esmagadora, homens inteiramente comprometidos e partidários das liberais políticas, da filosofia, da educação, frutos da profunda reforma pombalina. 


\subsection{TOLERÂNCIA RELIGIOSA AOS ANGLICANOS}

Naturalmente, celebraram-se vários tratados e acordos entre Portugal e Inglaterra. Com eles os ingleses desfrutaram de ampla liberdade para atracar seus navios em portos brasileiros. Houve um derrame e invasão de todo tipo de produtos ingleses nos mercados nacionais. A relação dos ingleses com Portugal e Brasil, foram adequadamente regulamentados por tratados bilaterais. Entre eles, estão: o Tratado de Aliança e Amizade e o Tratado de Comércio e Navegação, firmados em 1810.

O liberalismo político filosófico da elite Luso-brasileira, ficou adequadamente estampado nos artigos, principalmente no $12^{\circ}$ artigo do Tratado de Comércio $e$ Navegação. Nele fica estabelecido que os ingleses adeptos do culto protestante anglicano teriam todas as garantias e proteção para praticarem livremente o seu culto. Não seriam perturbados nem molestados, pelo contrário, desfrutariam caso fosse necessário, dar proteção das autoridades constituídas no país.

Aos ingleses que fossem permanecer no território brasileiro, foi autorizado a compra de propriedades e a construção de suas Capelas Anglicanas. Essas capelas deveriam na sua fachada externa ter a aparência de casas comuns. É vedado a utilização de símbolos cristãos, como o sino e a cruz. Teriam direito também a adquirirem terrenos para a construção de seus cemitérios. (RODRIGUES, op. cit., 1904)

O primeiro capelão anglicano a se estabelecer no Brasil foi Robert C. Crane, em 1816. A primeira capela foi inaugurada no Rio de Janeiro. Comenta Rodrigues: "Os Inglezes não perderam tempo na erecção de seu primeiro templo. Em agosto de 1819 lançaram a rua dos Barbonos desta Capital, a pedra fundamental da sua capella que foi também o primeiro templo protestante na América do Sul”. (RODRIGUES, op. cit., p.106)

Tornaram-se populares no Brasil, a Capela Anglicana, o clube e o cemitério dos ingleses.

Tais documentos assinalavam que constrangimentos, perseguições, inquisição ou qualquer outro instrumento cerceador quanto as liberdades de consciência e crenças, não seriam permitidos entre os lusos brasileiros estabelecidos no Brasil, Portugal e nas demais colônias. Estas decisões e decretos foram enorme avanço para a sociedade brasileira. Ao mesmo tempo, religiosos, representantes das tendências Ultramontanas/Tridentinas foram seriamente golpeados. 
Sem dúvida que o Padroado/Regalismo, da coroa e da nobreza era o fundamento para todo aquele comportamento liberal na direção dos acatólicos. Não se pode ignorar que o jansenismo com sua base teológica agostiniana, oferecia os elementos necessários para a consolidação do Regalismo ideológico. Ao mesmo tempo influenciava muitos sacerdotes a viverem um cristianismo austero e significativo, que ao mesmo tempo produzia inclinações ao apego e a leitura das escrituras sagradas.

A quantidade de padres e frades em cargos de importância na estrutura burocrática brasileira, não eram suficientes para impedir os novos avanços. A igreja não passava de um departamento burocrático no Estado. Movimentava-se com relativa dificuldade em razão de fortes limitações impostas pelo regime Regalista-Galicano do Imperador. Apesar da presença hegemônica do catolicismo no Brasil, há mais de três séculos, suas marcas pontuais eram desbotadas e com pouca credibilidade.

A escassez de bispos e padres, e nos últimos anos a extinção da Companhia de Jesus, diante de tão grande território, produziu uma frágil religiosidade que clamava por uma igreja com atuação mais direta, suprindo as necessidades básicas de um povo necessitado dos valores da religião.

Soma-se a isto muitos padres liberais, outros maçons e ainda a presença de outros com esposas, amasiados e outros não raros com amantes. Talvez aqui encontre-se, em parte a explicação para a pouca influência da igreja sobre os assuntos do Estado.

Imagina-se que as autoridades e a própria monarquia, ao se estabelecerem no Brasil eram portadores de ideias renovadoras para uma já carcomida administração conforme o modelo de domínio colonial.

Os novos tempos exigiam novos comportamentos, novas atitudes e uma compreensão que Portugal e Brasil, facilmente ocupariam as piores colocações no rol das nações modernas, caso não acompanhassem o movimento do mundo em transição.

Os legisladores, lusos brasileiros com a enorme responsabilidade de escrever e documentar os novos códigos que haveriam de regulamentar as políticas internas e a diplomacia internacional, não estavam alheias ou indiferentes as necessidades de melhorias para que o Brasil emergisse da condição de colônia para uma de reino e modernidade.

Com a sagração a rei do príncipe regente, agora D. João VI, em 06 de fevereiro de 1818, o Brasil é elevado a condição de reino, juntamente com Portugal e Algarves. 
Também aqui verificou-se o fim da opressão Napoleônica sobre a Europa e particularmente Portugal. As novas condições da Europa influenciaram Portugal a exigir a interrupção da regência inglesa sobre o seu estado e o retorno, o mais breve possível, da corte que para muitos estava no exílio brasileiro.

$\mathrm{Na}$ década de XX, vários acontecimentos agitaram a política brasileira, D. João VI retornou a Portugal, pondo fim a revolução do porto. Pedro I, proclamou a esperada independência com relação a Portugal, aclamado Imperador do Brasil, logo tomou providências para que seus legisladores organizassem uma Constituinte em 1823. Esta Constituinte trabalhava na organização da Primeira Constituição Imperial do Brasil. Sofreu intervenções direta do Imperador, que por fim responsabilizou uma comissão de número restrito a ultimar os trabalhos.

A referida comissão nomeada por D. Pedro I para finalizar a Constituição, segundo Tarcísio Beal, era composta, em grande parte por clérigos, cuja formação intelectual fundamentava-se na nova mentalidade oriunda das Reformas Pombalinas. (BEAL, 1976)

Para este estudo é necessário dizer que o artigo $5^{\circ}$ da referida Constituição de 1824, constitui-se em divisor de águas para o entendimento da tolerância religiosa e a permissão do culto acatólico em solo brasileiro.

\subsection{IMIGRAÇÃO GERMÂNICA}

Esta Constituição abria caminhos esperançosos para novos estrangeiros que cogitavam a possibilidade de fincar residências no Brasil. Brasileiros ao estenderem seus olhos para além das fronteiras do Brasil com as nações castelhanas não ignoravam que profundos movimentos de rupturas transformavam e garantiam não só a liberdade, mas também a implantação de regimes republicanos pelas nações irmãs.

Tais agitações e notícias não foram ignoradas por parcelas significativas da liderança política brasileira. $\mathrm{O}$ anseio pelo regime republicano, aqui no Brasil, era anterior a Proclamação da Independência. Cogitava-se também a libertação dos escravos e a quebra do monopólio religioso católico sobre os brasileiros. Infelizmente nenhuma destas agendas foram compridas. O país constituiu-se em monarquia em seu regime de governo, manteve a escravidão, tornando-a coluna da estrutura econômica e manteve o monopólio católico, ainda que sob o controle do padroado. Outras necessidades eram básicas a nação. 
Dentre elas, melhorias na agricultura e pecuária. Implantação de indústrias têxteis e o assentamento de brasileiros em bolsões fronteiriços, geralmente no Sul, evitando assim a invasão indesejada de castelhanos em solo nacional. Outro tema que muito agitou o século XIX, está diretamente ligado a ideias de branqueamento da raça, uma vez que o contingente da população negra no início do século XIX dobrava-se diante da sua correspondente branca.

A formação e o estabelecimento das novas comunidades protestantes no Brasil, comenta Grijp (s/d, p.6): "está relacionada a entrada de imigrantes e, portanto, com as necessidades socioeconômicas do Império nos seus primeiros anos”.

O governo imperial enfrentava grandes dificuldades com a escassez de escravos trabalhadores, cada vez mais consumidos pelas lavouras e a substituição destes por novos lotes oriundos do tráfico internacional.

Houve na década de XX um intenso movimento dos representantes do governo na direção da Europa Germânica propondo a quem quisesse, imensas garantias e segurança para fixarem-se no Brasil. Muitas propagandas, incluindo cartazes apresentavam aos germânicos e suíços o Brasil como se fosse a Nova Canaã.

Os primeiros imigrantes totalmente financiados pela coroa, ao aportarem no Rio de Janeiro, foram encaminhadas as regiões serranas daquela capital. Os novos moradores suíços católicos, em 1820, iniciaram a colônia de Nova Friburgo, logo a região foi abandonada e oferecida a alemães luteranos que chegaram em maio de 1824: um grupo de 324 imigrantes acompanhados do seu pastor, Friedrich Oswald Sauerbronn (17841864).

As políticas públicas favoreciam o estabelecimento de imigrantes ao ponto de chegarem em um número de 4800 até o ano de 1830. As regiões de Nova Friburgo, São Leopoldo e Santa Catarina, devido a políticas provinciais decentralizadas do governo imperial favoreciam estes colonos e ofereciam incentivos para atuarem em regiões ainda não povoadas e ao mesmo tempo oferecendo os seus braços nas produções agrícolas. Estas regiões acolheram os primeiros núcleos protestantes com suas igrejas e com seus pastores subvencionados pelo governo imperial. Consta-se que até o ano 1829, tinham 5 igrejas, atingindo o número de 61 no período de 1845 a 1864. (GRIJP, s/d) 


\subsection{COLPORTORES AMERICANOS}

A boa convivência, na primeira metade do século XIX, entre os Estados Unidos e o Brasil, proporcionaram intensas relações diplomáticas e comerciais. Grandes estruturas denominacionais americanas como a Igreja Metodista Episcopal, a Congregacional e a Presbiteriana, despertaram-se para a obra missionária no promissor campo brasileiro. Em 1835, já foi possível observar a presença de missionários Metodistas atuando diretamente na distribuição de bíblias e pregação do santo evangelho. Coube ao jovem ministro Fountain E. Pitts a hercúlia tarefa de dar início a projetos que consolidados, marcariam a origem e permanência da Igreja Metodista Episcopal entre os brasileiros. Após organizar no Rio de Janeiro, pequena sociedade de protestantes, prosseguiu viajando para Montevideo e Argentina, relatando suas observações quanto as condições para divulgação do evangelho naquelas regiões. No ano seguinte retornando aos Estados Unidos, prestou relatório a Conferência Geral da Igreja Metodista Episcopal, provocando grande euforia pois os campos estavam "prontos para a semeadura e colheita".

Grandes esforços foram empreendidos e a conferência, animada pelo relatório de Pitts, encarregou Justin R. Spaulding, com o propósito de se estabelecer na capital do império, dando assim continuidade ao núcleo estabelecido ali, anteriormente. Fruto do trabalho missionário do referido ministro estabeleceu-se na corte a primeira escola dominical no Brasil em 1836. No mesmo ano segundo Grijp (s/d), surgiu uma "escola diária", que incluíam alunos brasileiros, inclusive alguns filhos de escravos.

A chegada do missionário Daniel P. Kidder, muito contribuiu para o desenvolvimento do evangelho, como também para a distribuição de bíblias em muitas regiões e províncias do Brasil. Em 1837, Kidder ainda jovem não media esforços para cumprir de maneira metódica e continua suas obrigações de missionário. Além de ministro da Igreja Metodista, representava a sociedade bíblica americana, que via muitos resultados na distribuição da versão bíblica do Padre Antônio Pereira de Figueiredo.

Detalhados e precisos registros de suas longas viagens encontram-se nas páginas do seu precioso livro Reminiscências de viagens e permanência no Brasil. Encontram-se nesta obra situações inusitadas, curiosas e do retrato do Brasil naquela primeira metade do século XIX. Em distantes paragens foi hospedado por todo tipo de pessoas, inclusive padres. Com estes travou curiosos diálogos que revelavam, inclusive, as condições, acertos e erros destes. Kidder, demonstrava grande preocupação com os resultados que o 
catolicismo de senso comum, geralmente abandonado por seus líderes produzia na mentalidade e religiosidade do homem do campo.

Consumia o seu tempo com a pregação do evangelho e demonstrava grande prazer em distribuir a bíblia em língua portuguesa a todos que a reclamassem. Propaganda enérgica que consistia em: "não só pela pregação verbal como pelo derramamento de Bíblias, Testamentos e tratados ou opúsculos religiosos”. (RODRIGUES, 1904, p. 205)

Kidder demonstrava grande interesse em estabelecer contato com líderes políticos, religiosos, juristas e acadêmicos. Tendo a oportunidade de dialogar com membros da política paulista, formalmente ofertou a Assembleia Legislativa Novos Testamentos para serem encaminhados a todas as escolas públicas da província. Esta oferta foi considerada bastante generosa e por muito pouco teria sido aprovada, caso não acontecesse a intromissão e informações inverídicas oriundas de um padre inglês que afetado não via com bons olhos o projeto do missionário. (FLETCHER, 1941, p. 98)

Desta forma Kidder tornou-se o primeiro agente bíblico a efetivar com certa regularidade a distribuição de bíblias pelas regiões em que viajava. Criou também Sociedades de Temperança com ajuda de marinheiros, a fim de inibir o uso descontrolado de bebidas alcoólicas. O falecimento de sua esposa em 1842, o abalou e se viu obrigado a retornar a Nova York. Questões financeiras obrigaram a Igreja Metodista Episcopal, retirar do Brasil o missionário Rev. R. J. Spaulding em 1841. (RODRIGUES, 1904, p. 208)

Assim, a continuidade do trabalho Metodista em solo brasileiro foi interrompida, não por questões políticas ou algum tipo de perseguição. Se deu por questões internas e divisões no interior da denominação Metodista Episcopal. Com isso, o movimento protestante missionário se estagnou e apresentou certa retração por cerca de dez anos.

A década de 40, apresentou certa agitação política com o fim da regência e o início da segunda monarquia com Pedro II. No início da década de 50, os trabalhos protestantes foram reativados com a chegada do pastor presbiteriano Rev. James C. Fletcher.

Fixou-se no Rio o Rev. James C. Fletcher, que era presbiteriano, mas empenhou-se na obra evangélica na antiga Corte, sob os auspícios da União Cristã Americana e Estrangeira e da Sociedade dos Amigos para os Marinheiros. Viveu no Rio de 1851 a 1854. Como o seu colega Kidder, era homem de elevada cultura e teve ingresso nas altas rodas sociais. Por algum tempo foi secretário da legação americana. Frequentava o paço imperial e foi membro do Instituto Histórico e 
Geográfico Brasileiro. Voltou ao Brasil em 1855 e fez diversas viagens de evangelização pelo interior e pelo litoral. Associou-se a Kidder nas novas edições da obra citada, que foi refundida, tornando-se Fletcher o principal narrador. As viagens de Kidder e Fletcher e sua convivência com personagens na alta roda social serviram até certo ponto para desbravar o terreno, ocupando eles o papel de precursores para surtos mais vigorosos, que iam ser produzidos no terreno da propaganda religiosa, por missionários congregacionalistas, presbiterianos, metodistas, batistas e episcopais." (LESSA apud KIDDER, FLETCHER, 1941, p. XVI).

\subsection{PROTESTANTISMO MISSIONÁRIO - CONGREGACIONAIS}

O pastor presbiteriano James C. Fletcher, que além de agente da Sociedade Bíblica era também secretário da legação dos Estados Unidos e exercia funções pastorais para seus conterrâneos no Brasil, buscou desde 1854 alguns ajudantes para lhe servir de colportores, entrando, para tal efeito, em correspondência com Robert R. Kalley. (GRIJP, $\mathrm{s} / \mathrm{d})$

A chegada do Dr. Kalley aos Estados Unidos, constitui-se em um dos mais belos capítulos da Moderna História do Protestantismo. Estas páginas com fascinantes narrativas encontram-se na obra "Lembrança do Passado" de João Gomes da Rocha.

O Dr. Kalley cumpriu importante trabalho missionário na ilha da madeira. Infelizmente perseguições religiosas, o levou, juntamente com vários de seus paroquianos, a imigrarem para os Estados Unidos. Após difícil viagem, são cordial e respeitosamente recepcionados por autoridades americanas que não mediram esforços para atender as necessidades daqueles portugueses e do Sr. Kalley, surrados por longa e difícil travessia. Ficou registrado que até mesmo o comércio, com suas portas já cerradas, foi aberto para suprir aquela gente com gêneros de primeiras necessidades.

Após o seu estabelecimento nos Estados Unidos, o Dr. Kalley mantinha aspirações e interesses na evangelização e missões de comunidades de fala portuguesa. Foi nestas condições, que muito a propósito chegaram a ele correspondências do Rev. James C. Fletcher, solicitando ajuda e cooperação dos protestantes madeirenses para atender a grande demanda entre os brasileiros. As memórias do Rev. Kidder foram lidas pelo Rev. Kalley que de imediato passou a demonstrar grande interesse pelo trabalho missionário no Brasil. (ROCHA, s/d)

Em 10 de maio de 1855, chegou ao Rio de Janeiro, o médico escocês, com auxiliares para iniciarem o penoso trabalho da implantação do Protestantismo, mais 
solidificado, na corte brasileira. Estrategicamente, provavelmente motivados pelas difíceis experiências vivenciadas na Ilha da Madeira, o Dr. Kalley ocupa e instala-se na cidade de Petrópolis, objetivando certo estreitamento e proximidade com membros da coroa brasileira.

O humilde começo do trabalho do Dr. Kalley no bairro germânico de Petrópolis, conforme Testa (1963, p. 93), envolveu:

\begin{abstract}
As duas criadas alemãs e o jardineiro português que acompanhavam todas as noites o Dr. Kalley e a esposa nas orações familiares, marcaram o modesto começo dum grande movimento missionário que havia de culminar com o estabelecimento do Congregacionalismo no Brasil. A senhora Kalley organizou uma Escola Dominical que se reuniu pela primeira vez a 19 de agosto de 1855 , e, duas ou três semanas depois, deu início a primeira classe bíblica, para os portugueses do Rio. Com tão fracos começos, a primeira Igreja Evangélica para os portugueses do Brasil, foi fundada em 1856.
\end{abstract}

A medida em que os meses e anos foram passando, o Dr. Kalley com uma melhor compreensão do sistema jurídico, político e religioso da terra que o abriga, sentiu-se mais impulsionado a intensificar a sua obra missionária. Convidou amigos, velhos conhecidos a transportarem-se dos Estados Unidos para lhe auxiliarem no difícil trabalho.

Estabeleceu igrejas em Niterói e Recife dando assim maior visibilidade aos seus serviços religiosos, concomitante a um renovador e fraternal trabalho de assistência médica, a quantos necessitassem. O seu empolgante trabalho atraiu ilustres damas da sociedade fluminense. Tal ocorrência gerou a indignação e reprovação de religiosos insatisfeitos com o avanço do protestantismo. Especificamente nesta questão renomados juristas da corte, dispuseram-se a defender a causa da Igreja Evangélica Fluminense e do Dr. Kalley. O notável jurista Joaquim Nabuco defendeu e ganhou a causa do médico escocês.

Outra área de importante atuação deste casal de missionários foi a utilização, manutenção e a composição de "Hinos Sacros", motivo de inspiração para todas as comunidades evangélicas. Abaixo resumo das primeiras publicações do hinário "Salmos e Hinos". Relata Testa (1963, p.103-105):

Todavia, Dr. Kalley e sua esposa, Sarah, são mais conhecidos e lembrados pela grande e valiosa contribuição que deram a hinologia evangélica portuguesa. O "Salmos e Hinos", hinário usado pelos evangélicos de língua portuguesa em todo o mundo, seria bastante 
pobre sem os hinos e versões metrificadas de alguns salmos compostos e traduzidos pelos Kalleys.

A primeira edição de "Salmos e Hinos" publicada em 1861, contém cinquenta hinos, metade dos quais foram escritos pelo doutor e pela senhora Kalley. Quatro anos depois, seis novos hinos foram acrescentados, como num apêndice, ao hinário. Viajando pela Europa, em 1861, o Dr. Robert Reid Kalley mandou publicar a segunda edição de "Salmos e Hinos", em Lisboa. Nesta edição já aparece uma centena de hinos e salmos metrificados, alguns dos quais foram compostos por Mr. Richard Holden, o agente da Sociedade Bíblica Britânica no Rio de Janeiro. A quarta edição, publicada em Londres, no ano de 1873, já contava cento e trinta e um "cânticos sagrados". A quinta edição, também publicada em Londres, quatro anos mais tarde, incluía cento e oitenta hinos. A sétima e oitava edições foram feitas em Edimburgo e apresentavam mais vinte novos hinos. Com a autorização do Dr. Kalley, surgiram outras edições em Illinois, na Trindade e em Portugal e muitos hinos do "Salmos e Hinos" foram incluídos nos hinários evangélicos de Espanha, Mexico e Argentina. A edição mais recente de "Salmos e Hinos", publicada em 1959, contém seiscentos e oito hinos e salmos metrificados; a autoria de setenta e dois desses hinos é atribuída a Sarah Poulton Kalley, e treze ainda, a seu marido Robert Reid Kalley”.

O talento poético e musical da Senhora Kalley foi consagrado ao desenvolvimento duma hinologia para as comunidades evangélicas de língua portuguesa nos pontos mais diversos do Globo. Quer escrevendo hinos, quer compondo músicas, ensinando organistas para as igrejas, dirigindo os coros delas, ou ainda estabelecendo padrões para o cântico congregacional, o seu grande serviço prestado à primeira geração do Protestantismo brasileiro, foi singular e os benefícios das contribuições que ela deu são ainda apreciados com gratidão, um século depois”. (TESTA, 1963, p.106)

\subsection{PROTESTANTISMO MISSIONÁRIO - PRESBITERIANOS}

A pouca idade, a falta de experiência e apego ao núcleo familiar, não foram fatores impeditivos capazes de inibir o ímpeto de Ashbel Green Simonton, em considerar e decidir-se pelo Brasil como seu campo missionário.

O Board de Nova York, departamento de missões da Igreja Presbiteriana do Norte dos Estados Unidos, foi quem comissionou este pastor e sobre ele colocou a responsabilidade de oficializar e implantar o presbiterianismo entre os brasileiros. A sua chegada se deu no Rio de Janeiro em 12 de agosto de 1859. (SIMONTON, 2002)

Outros pastores presbiterianos, como foi o caso do Rev. Fletcher, desde 1851, com pequena interrupção entre 1854-1855, atuou incansavelmente, como foi dito anteriormente na distribuição de bíblias e outros impressos. No entanto não veio comissionado por organismos representativos das Igrejas Presbiterianas Americanas. 
Simonton ao se estabelecer na corte, pode, após observações, verificar que o campo era muito extenso e que ultrapassava os limites do Rio de Janeiro. De imediato travou contatos com o dr. Kalley e com este, após pequena rusga, manteve permanente amizade. Logo chegaram ao Brasil, atendendo solicitações do Rev. Simonton, o Rev. Alexander Latimer Blackford e sua esposa Elizabeth Simonton. Em seguida com o objetivo de atender comunidades de alemães na região de Rio Claro em São Paulo, chegou o Rev. Francis Joseph Christopher Schneider e algum tempo depois George Whitehill Chamberlain.

Estes missionários procuraram com certa urgência, visitar e conhecer, com maiores detalhes, as províncias de São Paulo, Paraná, Espírito Santo e Minas Gerais. Em 12 de janeiro de 1862, foi organizada a Primeira Igreja Presbiteriana no Brasil, com a recepção do americano Henry E. Milford e do português Camilo Cardoso de Jesus. O primeiro brasileiro a professar a fé entre os presbiterianos foi Serafim Pinto Ribeiro. Esta igreja, em muito serviu como plataforma para catapultar estes missionários para as regiões já citadas. No ano de 1863, enquanto o Rev. Simonton desfrutava de férias em sua pátria e dava encaminhamento para o seu casamento com a jovem Helen Murdoch, aqui no Brasil o Rev. Blackford conheceu o Padre José Manoel da Conceição, recluso em seu sítio na região de Corumbataí, e com este iniciou uma forte amizade. Cada vez mais em Blackford, fixava a convicção de definitivamente implantar igrejas na província de São Paulo, principalmente em sua capital.

Em 05 de novembro de 1864, saiu o primeiro número da Imprensa Evangélica. Infelizmente o ano de 1864 deixava tristes lembranças ao Rev. Simonton por ter falecido a sua jovem esposa em 28 de junho.

As ações missionarias na capital da província de São Paulo, criaram boas condições para que em 05 de março de 1865, fosse organizada a Primeira Igreja Presbiteriana em São Paulo. Logo em seguida em 13 de novembro do mesmo ano, organizou-se a Igreja Presbiteriana de Brotas, interior da província. Esta organização foi possível, graças a um operoso trabalho, ali desenvolvido pelo ex-padre José Manoel da Conceição, já, totalmente integrado ao presbiterianismo.

As três igrejas Rio de Janeiro, São Paulo e Brotas, abriram caminho para a organização em 16 de dezembro de 1865, do primeiro Presbitério constituído no Brasil recebendo o nome de Presbitério do Rio de Janeiro. Nesta reunião, em 17 de dezembro, 
José Manoel da Conceição foi ordenado ao Sagrado Ministério. Tornando-se o primeiro pastor brasileiro.

A necessidade de evangelistas e de uma liderança mais preparada, preferencialmente, de naturais da terra, levaram os pioneiros americanos a constituírem o seminário primitivo, funcionando no Rio de Janeiro em maio de 1867.

Modesto Perestrelo Barros de Carvalhosa, Miguel Gonçalves Torres, Antônio Bandeira Trajano e Antônio Pedro de Cerqueira Leite, os três primeiros portugueses, e o último brasileiro, foram os primeiros alunos da citada escola de pastores. Todos eles ao término do curso, por volta de 1870, prestaram prestimosos serviços a Igreja Presbiteriana e a educação no Brasil.

Foi neste mesmo ano, em São Paulo que a Sra. Mary Anneslay Chamberlain com o auxílio de seu esposo em sala de sua casa, iniciou com algumas crianças, o pequenino germe da escola que se desenvolveria metamorfoseando-se em Escola Americana.

Por volta de 1869 a Igreja Presbiteriana do Sul dos Estados Unidos, naturalmente, acompanhando as grandes movimentações de imigração para o Brasil, autorizou o Committee de Nashville a enviarem os reverendos Edward Lane e George Nash Morton. Fixaram residências em Campinas e de imediato mostraram-se extremamente competentes na disseminação do evangelho e na arte de organizar a sociedade. Várias foram as igrejas constituídas por eles, presbitérios, que no futuro, em 1888, comporiam o Sínodo Brasileiro. Como educadores criaram o famoso Colégio Internacional em Campinas no ano de 1873.

Algumas pesquisas demonstraram que o referido colégio, apesar da sua curta duração cumpriu um papel de relevante valor ao possibilitar e sociabilizar a educação a quantos se interessaram. Os primeiros anos foram intensos e movimentados. Logo chegaram para compor os seus quadros, missionárias, educadoras americanas: Nannie Henderson, Mary Videau Kirk e Charlotte Kemper.

Expandiram o campo de atuação para Minas Gerais e rapidamente alcançaram as terras pernambucanas no Nordeste. Grande parte dos esforços empreendidos veio através do incansável trabalho do Rev. John Boyle.

As duas missões, através de seus ministros e com campos de atuações bem definidos, tomaram a importante decisão de consultarem as igrejas mães, quanto a possibilidade de unificação. 
As consultas foram acolhidas e analisadas com interesse, recebendo a aprovação. A esta altura os missionários da igreja do sul tinham constituído o Presbitério Campinas Oeste de Minas e o Presbitério de Pernambuco.

Quanto aos missionários do Norte, ampliaram o número de igrejas jurisdicionadas pelo Presbitério do Rio de Janeiro.

Em 6 de setembro de 1888, ocorreu em importante reunião, a fusão das missões e a constituição do Primeiro Sínodo Brasileiro. Era, a tão esperada autonomia desta denominação.

O Primeiro Sínodo Brasileiro, admitiu como seu Sistema Teológico Eclesiástico Administrativo a Confissão de Fé de Westminster, o Catecismo Maior e Breve, o Livro de Ordem e o Diretório de Culto. Tais documentos constituem-se nos Símbolos de Fé da Igreja Presbiteriana em território brasileiro.

Os desafios que pastores e missionários encontraram ao final do século XIX, atuando na igreja, eram evidências que a Igreja Reformada deveria sempre estar se reformando para adequadamente responder as inquietações de um mundo em transição.

\subsection{PROTESTANTISMO MISSIONÁRIO - METODISTAS}

Muitos fatores, minunciosamente observados, contribuíram para a escolha do Brasil, como refúgio e implantação de colônias americanas. Depauperados, eles, atingidos no orgulho e nas suas consciências pelos resultados e fracassos da guerra de secessão (1861-1865), não se sentiram mais à vontade em seus estados de origem, sendo obrigados a buscarem outros países que lhes oferecessem renovo existencial.

Logo que chegaram ao Brasil se instalaram nas regiões de Campinas, Santa Barbara e a atualmente Americana. Entre os novos colonos havia metodistas, batistas, presbiterianos, entre outros. Também ali verificou-se a presença de ministros protestantes que acompanhavam membros de suas antigas congregações.

"O pastor Newman, metodista, ativo na área das colônias desde 1869, estendeu lentamente a esfera da sua influência na população brasileira, até deslocar sua residência, dez anos mais tarde, para a cidade paulistana de Piracicaba. Ajudado por suas filhas, abriu ali um colégio com internato". (GRIJP, s/d, p.16) 
O Rev. John James Ranson por algum tempo, no meado da década de 70, conviveu com os presbiterianos no Colégio Internacional de Campinas. Mudou-se para o Rio de Janeiro e iniciou núcleo de metodistas, cujo resultado imediato foi a organização de uma igreja desta denominação. Fato este, simbolicamente remetiam e conectavam esses irmãos ao primeiro grupo que precisou encerrar suas atividades aqui no Brasil com os reverendos Kidder e Justin Spauding no início da década de 40.

Em 1881, chegaram importantes reforços ao Brasil para auxiliar e divulgar e consolidar o trabalho metodista. O primeiro deles foi o Rev. J.W. Koger, que instalandose em Piracicaba, organizou uma igreja. Outra presença marcante foi Martha H. Watts, que impulsionou o colégio sob sua direção. "E ainda o jovem James L. Kennedy, que havia de servir a causa do metodismo brasileiro até sua morte em 1943." (GRIJP, s/d, p. 16)

A década de 80, foi muito promissora para os metodistas. Dividiram o campo de atuação entre São Paulo e Rio de Janeiro. A superintendência do trabalho ficou sob a responsabilidade do Rev. Koger. Ranson e Kennedy, cooperaram ativamente com os trabalhos na corte. Com certa liberdade Ranson desenvolveu frutífero ministério itinerante conforme a essência do metodismo. Estabeleceu-se igreja na capital da província de São Paulo e ocuparam regiões na província do Espírito Santo. Criaram o jornal "O Expositor Cristão" e ainda receberam a visita do bispo J.C. Granbery no ano de 1886, quando foram dados os primeiros passos para a organização da Igreja Metodista no Brasil.

\subsection{PROTESTANTISMO MISSIONÁRIO - BATISTAS}

A missão batista no Brasil começou em 1881, quando o jovem texano William B. Bagby, encarregado da Convenção Batista do Sul, assumiu o pastorado entre seus correligionários americanos de Santa Barbara d'Oeste. No ano seguinte juntou-se com ele outro missionário, Zacharias C. Taylor, assim como o ex-padre Antônio Teixeira de Albuquerque, que fora recebido por Ranson em 1879 como primeiro membro brasileiro da igreja metodista do Rio, mas que depois aderiu aos princípios batistas, chegando a ser também o primeiro adepto brasileiro desta denominação. (GRIJP, s/d)

Por algum motivo o Nordeste particularmente a capital da província baiana, atraiu os pastores Bagby e sua esposa, Taylor, além do ex-padre Albuquerque. Com dificuldades em 1882, estabeleceram uma pequena igreja batista. Aos poucos, utilizando literaturas 
apologéticas como a "Três razões porque deixei a Igreja de Roma", folheto que testemunhava a experiência do ex-padre, que fez muito sucesso.

Igrejas batistas foram iniciadas em Maceió (1885), Recife (1886) e no Rio de Janeiro (1884). Enquanto o pastor Taylor ampliava seu campo de trabalho com a abertura de algumas congregações no interior da província, despertando a atenção de seus auditórios com batismos públicos nas praias. Taylor, também preocupado com a escassez de liderança, organizou cursos preparatórios de teologia para equipar as novas lideranças. O pastor Bagby sentindo-se motivado a constituir Igrejas Batistas no Sul, mudou-se para o Rio de Janeiro e em 1884, e organizou a Primeira Igreja Batista do Rio de Janeiro, com quatro membros. Trabalho penoso, pois, outras tradições protestantes já estavam bem estabelecidas, ali, por vários anos. Com a insistência do referido pastor, americanos e brasileiros foram se filiando ao trabalho que logo em seguida colhia excelentes frutos. A junta missionária de Richmond, responsável pelos pastores e suas famílias, não ficou indiferente as necessidades dos campos e de seus missionários, mandando em seguida treze novos missionários para atender o clamor de Bagby.

Alguns destes missionários tiveram grandes lutas aqui no Brasil com doenças tropicais, levando-os até mesmo a morte. Por volta de 1889, o número de batistas ultrapassava a casa dos trezentos. No entanto, nos anos que se seguiram, esta denominação atingiu números surpreendentes ultrapassando, inclusive as demais denominações coirmãs.

\section{CONSIDERAÇÕES FINAIS}

A literatura produzida pelos reformadores do século XVI, bem como suas várias biografias, confirmam a completa dependência que cada um deles tinha pela Sagrada Escritura. Eram defensores das liberdades, tanto de consciência, como de política e da religião. Apreciavam a educação e criam que cada homem é responsável por si, perante o Criador. Também acreditavam, que todas as esferas do conhecimento e da vida, subordinavam-se a Deus que é o Soberano.

Ao término deste artigo, após as considerações sobre a França Antártica, o Brasil Holandês, Os Primeiros Colportores e as Denominações, que aqui se fixaram, conclui-se que os protestantes ao lançarem os seus fundamentos históricos e teológicos, aqui no Brasil, estavam oferecendo uma inovadora contribuição para a evolução e desenvolvimento do povo brasileiro. 
Assim, encerra-se com as palavras de Rui Barbosa:

O Protestantismo nasceu da liberdade da consciência individual, cuja consequência política é a liberdade religiosa; do protestantismo é filha a instrução popular, que constitui a grande característica, o principal instrumento e a necessidade vital da civilização moderna. (BARBOSA, 1945, p. 164)

Wilson Santana

Universidade Presbiteriana Mackenzie- 30.06.2021

\section{REFERÊNCIAS BIBLIOGRAFICAS}

AVELAR, Hélio de Alcântara. História administrativa do Brasil; administração pombalina. Brasília: FUNCEP/Ed. Universidade de Brasília, 1983.

BARbOSA, Rui. Discursos Parlamentares Câmara dos Deputados. Ministério da Educação e Saúde, Rio de Janeiro, 1945.

BARLÉU, Gaspar. História dos feitos recentemente praticados durante oito anos no Brasil. Belo Horizonte, ed. Itatiaia; São Paulo, Ed. da Universidade de São Paulo, 1974.

BARRETO, Lima. Triste fim de Policarpo quaresma: Orientação pedagógica e notas de leitura Douglas Tufano. 5 ed. Editora Moderna. São Paulo: 2015.

BEAL, Tarcísio. As raízes do regalismo brasileiro. Revista de história ${ }^{\circ} 108$, Vol. LIV. Ano XXVII. Disponível em:<https://www.revistas.usp.br/revhistoria/article/view/77808/81792>. Acesso em: 27/06/2021.

BONNICHON, Philippe. A França Antártica in História Naval Brasileira - $1^{\circ}$ volume tomo 2. Rio de Janeiro: Serviço de Documentação Geral da Marinha, 1975.

CERTEAU, Michel de. A Escrita da história. Rio de Janeiro: Forense Universitária, 1982.

FREIRE, Gilberto. Tempo de Aprendiz - Volume 1 e 2. São Paulo: IBRASA; (Brasília): INL, 1979.

GRIJP, Klaus Van der. História do Protestantismo Brasileiro. Monografia não editada, São Leopoldo, s/d.

KIDDER, Daniel P. Reminiscência de Viagens e Permanência no Brasil (Rio de Janeiro e Província de São Paulo). São Paulo: Livraria Martins, 1940.

KIDDER, D. P.; FLETCHER, J.C. O Brasil e os Brasileiros $-1^{\circ}$ e $2^{\circ}$ Volume. São Paulo, Rio de Janeiro, Recife, Porto Alegre: Companhia Editora Nacional, 1941. LÉRY, Jean de. Viagem á Terra do Brasil. Belo Horizonte: Editora Itatiaia, 2007.

LESSA, Vicente Themudo. Mauricio de Nassau, o Brasileiro. São Paulo: Edições Cultura Brasileira S/A, 1937. 
MOURA, Paulo Viana. Escola de Pastores Elite Intelectual e Presbiterianismo Dissertação de Mestrado. São Paulo: Universidade Mackenzie, 1995.

NETO, José Antonio Gonsalves de Melo. Tempos dos Flamengos. Rio de Janeiro: Livraria José Olympio Editora, 1947.

PISO, Guilherme. História Natural e Médica da Índia Ocidental. Rio de Janeiro: Ministério da Educação e Cultura, Instituto Nacional do Livro, 1957.

RIBEIRO, Domingos. Origens do evangelismo Brasileiro. Rio de Janeiro: Est. Graf. Apollo, 1937.

RIBEIRO, Boanerges. O Protestantismo no Brasil Monárquico. São Paulo: Pioneira, 1973.

ROCHA, João Gomes da. Lembranças do Passado. Rio de Janeiro: Centro Brasileiro de Publicidade Ltda, s/d.

RODRIGUES, J.C. Religiões Acatholicas no Brazil. Rio de Janeiro: Escriptorio do Jornal do Commercio, 1904.

SALVADOR, José Gonçalves. Vozes da História. São Paulo: Humanitas/FFLCH/USP, 2001.

SANTANA, Wilson. A Reforma Protestante e o Brasil: memorial 500 anos uma nova biblio-historiografia. Goiânia: editora Cruz, 2017.

SIMONTON, Ashbel Green. O Diário de Simonton 1852 - 1866. São Paulo: Editora Cultura Cristã, 2002

SOUTO MAIOR, Pedro. Fastos Pernambucanos. Recife: CEPE, 1991.

STADEN, Hans. Duas Viagens ao Brasil. Belo Horizonte, ed. Itatiaia; São Paulo, Ed. da Universidade de São Paulo, 1988.

TESTA, Michael P. O Apóstolo da Madeira. Lisboa: Papelaria Fernandes, 1963.

THEVET, André. As Singularidades da França Antártica. Belo Horizonte: Ed. Itatiaia; São Paulo: Ed. da Universidade de São Paulo, 1978.

VIANA, Marcia Serra Ribeiro. As Missões Presbiterianas Norte Americanas no Brasil de 1859-1924: Conceito e Instituição - Tese de doutorado. São Bernardo do Campo, Universidade Metodista de São Paulo, 2002.

VIEIRA, Padre Antonio. A Invasão Holandesa da Bahia. Salvador: Livraria Progresso Editora, 1955. 